\title{
Sex Determination from Occipital Condylar Measurements by Baudoin Index in Forensic Purposes
}

\author{
Determinación del Sexo desde Mediciones del Cóndilo Occipital \\ Mediante el Índice de Baudoin con Propósitos Forenses
}

\begin{abstract}
Osvaldo Fortes de Oliviera*; Rachel Lima Ribeiro Tinoco*; Eduardo Daruge Júnior**; Laís Gomes de Araujo ${ }^{* * *}$; Ricardo Henrique Alves da Silva**** \& Luiz Renato Paranhos ${ }^{* * * * * *}$
\end{abstract}

OLIVEIRA, O. F.; TINOCO, R. L. R.; DARUGE JÚNIOR, E.; ARAUJO, L. G.; SILVA, R. H. A. \& PARANHOS, L. R. Sex determination from occipital condylar measurements by baudoin index in forensic porpoises. Int. J. Morphol., 31(4):1297-1300, 2013.

SUMMARY: In human identification for forensic purposes the sex is one of the most important and first features to be assessed in each case. Baudoin condylar index is a sex determination method based on measurements of length and width of the occipital condyle. The aim of this research was to apply the Baudoin condylar index for sex determination, and evaluate its reliability. The sample was composed of 100 Brazilian human skulls, 50 male and 50 female from São Gonçalo cemetery, City of Cuiabá, Brazil. The measurement values were statistically analyzed in order to compare the matching rate for each sex, each side, as well as the overall average. The results showed that the overall percentage of success in applying the Baudoin index was $44.83 \%$ to males, and $51.93 \%$ to females, amounting to $47.5 \%$ matching. The accuracy of the Baudoin index to sex determination was quite low for this Brazilian sample, the reason why this method should be disregarded as a criterion to sexing skulls in a forensic context.

KEY WORDS: Forensic dentistry; Forensic anthropology; Sex determination analysis; Skull.

\section{INTRODUCTION}

Forensic human identification is commonly achieved by fingerprint analysis. However, this method may not be generally used due to soft tissue destruction, carbonization, or decomposition. In these cases, forensic anthropology arises as a reliable method of human identification, since its interprets information in the skeleton, determining basic features as sex, age, stature and ancestry, as well as particular characteristics, ideally pointing out only to one person (Gonzalez et al., 2011; Graw et al., 2005; Patil \& Mody, 2005; White et al., 2011).

Sex determination may be achieved by qualitative methods based in morphological evaluation of bone structures, or by quantitative methods based in anatomical measurements and indexes. The occipital condyle is one of the anatomical elements with sexual dimorphism, for it has been used in metric and morphological evaluation (Gapert et al., 2009; Machado et al., 2005; Suazo et al., 2009; Suazo et al., 2010). The Baudoin index (BI) was created to assess the sexual dimorphism based on measurements of length and width of the occipital condyle (Machado et al.; Suazo et al., 2010).
The local evaluation of population-specific features is deemed to have fundamental value regarding the application and reliability of anthropological methods to human identification. Therefore, the aim of this study was to apply the Baudoin condylar index to sex determination, and evaluate its accuracy for a Brazilian contemporary sample.

\section{MATERIAL AND METHOD}

We analyzed 100 human skulls, 50 males and 50 females, belonging to the collection of the São Gonçalo cemetery, in the city of Cuiabá, State of Mato Grosso, Brazil. Using convenience sampling, the skulls which met the eligibility criteria were selected. The criteria for inclusion were those skulls with complete registration of sex and age, belonging to adults (over 22 years old), which were in a state of preservation allowing measurement. We excluded those which had a history of trauma, gross asymmetry or taphonomic damage.

* Department of Forensic Dentistry, Piracicaba Dental School, State University of Campinas, Piracicaba, São Paulo, Brazil.

** Professor of Forensic Dentistry, Piracicaba Dental School, State University of Campinas, Piracicaba, São Paulo, Brazil.

*** Forensic Dentistry, School of Dentistry of Ribeirao Preto, University of São Paulo, São Paulo, Brazil.

***** Professor, Forensic Dentistry, School of Dentistry of Ribeirao Preto, University of São Paulo, São Paulo, Brazil.

****** Professor, Department of Dentistry, Federal University of Sergipe, Lagarto, SE, Brazil. 
Using a digital caliper with accuracy of $0.01 \mathrm{~mm}$ (Digimess ${ }^{\circledR}$, São Paulo, Brazil), the length and width of the right and left occipital condyles were directly determined. All the measurements were performed by a single examiner, with zero setting of the caliper tips before every new measurement, in order to avoid small variations of the equipment provoking bias in the outcome.

Using the software SPSS 15.0, statistical descriptors were calculated from the measurements, and the averages for each sex were analyzed by Student's t-test, and those with $\mathrm{p}<0.05$ were considered significant.

The diagnostic value of the Baudoin index was analyzed to determine the level of agreement in the diagnosis between the left side and right side, the accuracy of the method, sensitivity, and the positive predictive value for each sex. Classification according to the Baudoin condylar index represented by the following formula, with score greater than 55 points to female; score below 50 points to male; score between 50 and 55 remains inconclusive (Gapert et al., 2009).

Baudoin condylar index $=$ (maximum width of the condyle/ maximum length of the condyle) $x 100$

The measurements were repeated in $25 \%$ of the sample after a two-weeks interval to assess the intraexaminer reliability. In order to assess random error, the test proposed by Dahlberg (Houston, 1983) was used: error $=\sqrt{ } \Sigma \mathrm{d}^{2} / 2 \mathrm{n}$, where $\mathrm{d}=$ difference between 1 st and $2 \mathrm{nd}$ measurements, and $\mathrm{n}=$ number of repetitions.

\section{RESULTS}

According to the Student's t-test for paired samples, there was no intra-examiner error statistically significant; the same was observed in the systematic and random error assessed by Dahlberg's formula (Houston) (Table I). The comparison between the sexes regarding the average values of length and width of both condyles analyzed by Student's t-test showed sexual dimorphism statistically significant, taking into account both sides together, with males presenting higher measurements (Table II). In the right condyle examination, the males presented the greater average Baudoin index; females had the highest average when only the left condyle is considered (Table III).

The interpretation of the Baudoin condylar index (mean of both sides) has pointed to be male 43 skulls, from which only 19 (44.1\%) matched; among the 28 skulls supposed to be female according to the index, only $14(50 \%)$ matched. Twentynine skulls had scores between 50 and 55, and remained in the overlapping zone without conclusion. Upon analyzing the right and left sides separately, the success rate was lower for the right side (45.2\%), and slightly higher for left side (51.3\%). The final success rate was $44.83 \%$ for males, and $51.93 \%$ for females, totalizing $47.5 \%$ of matching, as shown in Table IV.

Table I. Mean, standard deviation of the measurements, Student's t-test and Dahlberg's error for systematic and casual error.

\begin{tabular}{|c|c|c|c|c|c|c|c|c|}
\hline & \multirow{2}{*}{ Measure } & \multicolumn{2}{|c|}{$1^{\text {st }}$ Measurement } & \multicolumn{2}{|c|}{$2^{\text {nd }}$ Measurement } & \multirow{2}{*}{$\mathbf{t}$} & \multirow{2}{*}{$\mathbf{p}$} & \multirow{2}{*}{ Error } \\
\hline & & Mean & SD & Mean & SD & & & \\
\hline \multirow{2}{*}{ 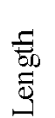 } & Right condyle & 27.24 & 3.11 & 27.15 & 3.01 & 0.484 & $0.633^{*}$ & 0.70 \\
\hline & Left condyle & 26.77 & 2.97 & 26.73 & 3.24 & 0.218 & $0.829 *$ & 0.62 \\
\hline \multirow{2}{*}{ 言 } & Right condyle & 12.36 & 1.56 & 12.46 & 1.54 & 1.361 & $0.186^{*}$ & 0.28 \\
\hline & Left condyle & 12.51 & 1.63 & 12.52 & 1.72 & 0.019 & $0.985^{*}$ & 0.37 \\
\hline
\end{tabular}

Table II. Difference between the mean of both sexes by Student's t-test.

\begin{tabular}{|c|c|c|c|c|c|c|}
\hline & \multirow{2}{*}{ Measure } & \multicolumn{2}{|c|}{ Male } & \multicolumn{2}{|c|}{ Female } & \multirow{2}{*}{$p$} \\
\hline & & Mean & SD & Mean & SD & \\
\hline \multirow{4}{*}{ 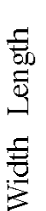 } & Right condyle & 26.74 & 2.96 & 25.45 & 3.21 & $0.038 *$ \\
\hline & Left condyle & 26.85 & 2.97 & 24.65 & 3.23 & $0.001 *$ \\
\hline & Right condyle & 13.51 & 1.38 & 12.68 & 1.56 & $0.006 *$ \\
\hline & Left condyle & 13.79 & 1.39 & 12.71 & 1.75 & $0.001 *$ \\
\hline
\end{tabular}


Table III. Mean value obtained by the Baudoin index for both sexes.

\begin{tabular}{lcc}
\hline & Male average & Female average \\
\hline Right condyle & 51.55 & 51.35 \\
Left condyle & 51.86 & 52.39 \\
Average for both sides & 51.67 & 50.54 \\
\hline
\end{tabular}

Table IV. Classification and success rates by applying the Baudoin index.

\begin{tabular}{|c|c|c|c|c|c|c|}
\hline & $\begin{array}{l}\text { Classified } \\
\text { as male } \\
(X<50) \\
\end{array}$ & Success rate & $\begin{array}{c}\text { Classified } \\
\text { as female } \\
(X>55)\end{array}$ & Success rate & $\begin{array}{c}\text { Inconclusive } \\
\text { range } \\
(50<X<55)\end{array}$ & $\begin{array}{l}\text { Success } \\
\text { rate for } \\
\text { both sexes }\end{array}$ \\
\hline Right side index & 49 & $21(42.8 \%)$ & 24 & $12(50 \%)$ & 27 & $45.2 \%$ \\
\hline Left side index & 42 & $20(47.6 \%)$ & 34 & $19(55.8 \%)$ & 24 & $51.3 \%$ \\
\hline Mean index (both sides) & 43 & $19(44.1 \%)$ & 28 & $14(50 \%)$ & 29 & $46 \%$ \\
\hline Mean & & $44.83 \%$ & & $51.93 \%$ & & $47.5 \%$ \\
\hline
\end{tabular}

\section{DISCUSSION}

This research has tested the sex determination through a quantitative method, and statistical analysis by Student's ttest due to its greater objectivity, according to other authors who stated that this kind of method overcomes the subjectivity bias of morphological features, being more reliable and reproducible (Patil \& Mody; Steyn \& Iscan, 1998).

The skulls included in the sample belong to a Brazilian region with a high degree of interethnic mixture between Amerindians, Africans and Europeans, especially Portuguese. The human variation of craniometrical patterns is observable from one population to another, being affected by ancestry, geography, weather, diet, culture, and sociological factors. The accuracy of sex determination methods in highly interbred populations is usually lower than in areas with ethnic predominance of a single group, as in Central Europe (Byers, 2010; Naikmasur et al., 2010; Suazo et al., 2010).

The anthropological characteristics should be analyzed in specific populations, specially to the different racial characteristics found in each region of the world. The samples used in the study are a limiting factor in research, once they were not selected by the racial characteristic, because it is a mixed population, thus discrepancies in the results may occur. Moreover, age and skin complexion are other factors which may contribute to possible changes in the outcome.

The result has proven that both length and width of the occipital condyle have higher mean value in males, which agrees with other anthropological researches of sex determination by craniometrical variation (Duric et al., 2005; Günay \& Altinkök, 2000; Machado et al.; Kemkes \& Gobel, 2006; Kimmerle et al., 2008; Kranioti et al., 2008; Monticelli \& Graw, 2008; Naikmasur et al.).
Despite being a method recommended by many authors (Francesquini Júnior et al., 2007; Franklin et al., 2005; Gonzalez et al.; Graw et al.; Günay \& Altinkök; Kemkes \& Gobel; Kimmerle et al.; Kranioti et al.; Machado et al.; Monticelli \& Graw; Naikmasur et al.; Patil \& Mody; Suazo et al., 2009, 2010; Teke et al., 2007; Veyre-Goulet et al., 2008; White et al.). Suazo et al. (2010) verified that the Baudoin condylar index has a low yield as a diagnostic test for determining the sex in the skulls studied. This situation can be explained by observing methods currently in use to assess the accuracy of diagnostic tests, they are mainly based on the analysis of differences with statistical significance, which in our study was, on the other hand, by calculating the percentage of success. The success rate of the Baudoin index for sex determination was $44.83 \%$ to the skulls classified as males, and $51.93 \%$ to the supposedly females, amounting an average of $47.5 \%$ when considering both sexes together. This result was higher than that found by Suazo et al. (2010) who obtained a success rate of $41.39 \%$, but lower than the results of Machado et al., who has shown $58.1 \%$ of accuracy.

When determining the sex of a human skull, the randomly guessing would present an average accuracy of 50\%, since theoretically the guess would be right in half of the cases (White et al.). The Baudoin index has achieved, in this sample, a success rate of $47.5 \%$, which does not increase the accuracy already existing by simple guessing. These findings are in agreement with Machado et al. and Suazo, et al. (2010) who had also tested this method in Brazilian samples.

The results of this study allow concluding that, on sexing a supposedly Brazilian human skull, the Baudoin index should be disregarded by the forensic expert, since it does not collaborate as additional criterion. There are many 
other craniometric methods of sex determination available in scientific literature, and those with low accuracy may confuse the judging of the investigators.

OLIVEIRA, O. F.; TINOCO, R. L. R.; DARUGE JÚNIOR, E.; ARAUJO, L. G.; SILVA, R. H. A. \& PARANHOS, L. R. Determinación del sexo a partir de mediciones de cóndilo occipital mediante el índice de Baudoin con propósitos forenses. Int. J. Morphol., 31(4):1297-1300, 2013

RESUMEN: En la identificación de personas con fines forenses el sexo es una de las características más importantes y primordiales a evaluar en cada caso. El índice condilar Baudoin es un método de determinación del sexo basado en mediciones de la longitud y la anchura del cóndilo occipital. El objetivo de esta investigación fue aplicar el índice condilar de Baudoin para la determinación del sexo, y evaluar su fiabilidad. La muestra fue compuesta de 100 cráneos humanos brasileños, 50 hombres y 50 mujeres del cementerio São Gonçalo, ciudad de Cuiabá, Brasil. Los valores de medición se analizaron estadísticamente con el fin de comparar la tasa de coincidencia para cada sexo, cada lado, además de la media general. Los resultados mostraron que el porcentaje general de éxito en la aplicación del índice de Baudoin fue de 44,83\% para los hombres y 51,93\% para las mujeres, lo que asciende a una coincidencia del 47,5\%. La precisión del índice de Baudoin para la determinación del sexo fue bastante baja para esta muestra brasileña, por lo que este método debe ser considerado como criterio para determinar el sexo de los cráneos en un contexto forense.

PALABRAS CLAVE: Odontología forense; Antropología forense; Análisis de determinación del sexo; Craneo.

\section{REFERENCES}

Byers, S. N. Introduction to forensic anthropology. 3th ed. Boston, Pearson, 2010.

Duric, M.; Rakocevic, Z. \& Donic, D. The reliability of sex determination of skeletons from forensic context in the Balkans. Forensic Sci. Int., 147(2-3):159-64, 2005.

Francesquini Júnior, L.; Francesquini, M. A.; De La Cruz, B. M.; Pereira, S. D.; Ambrosano, G. M.; Barbosa, C. M.; Daruge Júnior, E.; Del Bel Cury, A. A. \& Daruge, E. Identification of sex using cranial base measurements. J. Forensic Odontostomatol., 25(1):7-11, 2007.

Franklin, D.; Freedman, L. \& Milne, N. Sexual dimorphism and discriminant function sexing in indigenous South African crania. Homo, 55(3):21328, 2005 .

Gapert, R.; Black, S. \& Last, J. Sex determination from the occipital condyle: discriminant function analysis in an eighteenth and nineteenth century British sample. Am. J. Phys. Anthropol., 138(4):384-94, 2009.

Gonzalez, P. N.; Bernal, V. \& Perez, S. I. Analysis of sexual dimorphism of craniofacial traits using geometric morphometric techniques. Int. J. Osteoarchaeol., 21(1):82-91, 2011.

Graw, M.; Wahl, J. \& Ahlbrecht, M. Course of the meatus acusticus internus as criterion for sex differentiation. Forensic Sci. Int., 147(2-3):113-7, 2005.
Günay, Y. \& Altinkök, M. The value of the size of foramen magnum in sex determination. J. Clin. Forensic Med., 7(3):147-9, 2000.

Houston, W. J. The analysis of errors in orthodontic measurements. Am. J. Orthod., 83(5):382-90, 1983.

Kemkes, A. \& Gobel, T. Metric assessment of the "mastoid triangle" for sex determination: a validation study. J. Forensic. Sci., 51(5):985-9, 2006.

Kimmerle, E. H.; Ross, A. \& Slice, D. Sexual dimorphism in America: Geometric morphometric analysis of the craniofacial region. J. Forensic. Sci., 53(1):54-7, 2008.

Kranioti, E. F.; Iscan, M. Y. \& Michalodimitrakis, M. Craniometric analysis of the modern Cretan population. Forensic Sci. Int., 180(2-3):110.e1-5, 2008 .

Machado, S. R.; Marques, M. R.; Cardoso, L. M.; Souza, S. B.; Galvão, L. C. C. \& Marques, J. A. M. Applicability verification by "Baudoin" index for sex determination. Revista de Medicina Legal, Direito Médico e da Saúde, 1(3):36-8, 2005

Monticelli, F. \& Graw, M. Investigation on the reliability of determining sex from the human zygomaticum. Forensic Sci. Med. Pathol., 4(3):181-6, 2008.

Naikmasur, V. G.; Shrivastava, R. \& Mutalik, S. Determination of sex in South Indians and immigrant Tibetans from cephalometric analysis and discriminant functions. Forensic Sci. Int., 197(1-3):122.e1-6, 2010.

Patil, K. R. \& Mody, R.N. Determination of sex by discriminant function analysis and stature by regression analysis: a lateral cephalometric study. Forensic Sci. Int., 147(2-3):175-80, 2005.

Steyn, M. \& Iscan, M. Y. Sexual dimorphism in the crania and mandibles of South Africa whites. Forensic Sci. Int., 98(1-2):9-16, 1998.

Suazo, G. I. C.; Zavando, M. D. A.; Russo, P. \& Smith, R. L. Evaluation of the Baudoin Condylar Index diagnostic test for sex determination. Int. J. Morphol., 28(1):171-4, 2010.

Suazo, G. I. C.; Zavando, M. D. A. \& Smith, R. L. Performance evaluation as a diagnostic test for traditional methods for forensic identification sex. Int. J. Morphol., 27(2):381-6, 2009.

Teke, H. Y.; Duran, S.; Canturk, M. \& Canturk, N. Determination of gender by measuring the size of the maxillary sinuses in computerized tomography scans. Surg. Radiol. Anat., 29(1):9-13, 2007.

Veyre-Goulet, A. S.; Mercier, C.; Robin, O. \& Guérin, C. Recent human sexual dimorphism study using cephalometric plots on lateral teleradiography and discriminant function analysis. J. Forensic Sci., 53(4):786-9, 2008.

White, T. D.; Black, M. T. \& Folkens, P. A. Human osteology. 3th ed. Boston, Academic Press, 2011.

Correspondence to:

Luiz Renato Paranhos

Rua Padre Roque, 958

Centro, Mogi Mirim/SP

CEP: 13800-033

Received: 25-02-2013

BRAZIL

Accepted: 16-09-2013

Email: paranhos@ortodontista.com.br 